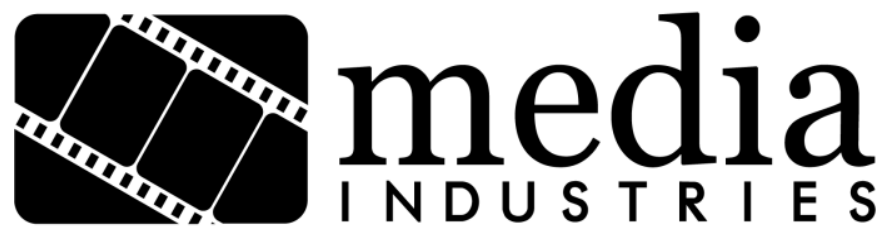

\title{
The Film Festival as an Industry Node
}

\author{
Dina Iordanova' \\ University of St. Andrews \\ dina.iordanova [AT] st-andrews.ac.uk
}

\begin{abstract}
:
In recent years, an increasing number of film festivals have engaged closely with film production and distribution. This engagement has been realized via a variety of festival-specific models, such as talent campuses, pitching sessions, project funding, distribution labels, streaming platforms, and so on. Thus, the film festival (which, as I have argued elsewhere, has essentially been an exhibition vehicle) is transforming from primarily a display site of completed films into an important factor that often triggers the very cycle of a film's conception, financing, development, production, and circulation. This short essay outlines the changing status of the film festival as a cluster of creativity and commerce and as a node in more general transnational infrastructures. It comments on the status of scholarship and sets out priorities for research.
\end{abstract}

Keywords: Film, Production, Distribution, Exhibition, Festival, Marketing

Today, it has become the norm that film festivals not only show films but also engage with film production and distribution. A variety of models that facilitate this engagement have come about, including talent campuses or filmmaking academies geared toward fostering new talent, preproduction or midproduction pitching sessions meant to create an additional investment stream for the project, and so on. Some festivals have created their own distribution labels, while others have teamed up with TV channels or with specific streaming platforms. These developments have resulted in a situation where the film festival is no longer mainly an exhibition operation (as I argued in my 2009 essay "The Film Festival Circuit"), ${ }^{2}$ but becomes a participant in many other aspects of the creative cycle-such as production financing, networking, and distribution - and thus turns into a key player in the film industry, as well as society at large. Indeed, it is increasingly the case that film festivals bridge the film industry with politics and other spheres. In a globalized context, it is the film festivals' inherent transnationalism that counterbalances nationalist tendencies, thus facilitating exchanges in production and circulation. This short essay outlines the changing status of the film festival as a cluster of creativity and commerce and as a node in more general transnational infrastructures.

Traditional classifications of film festivals include a category for the "business" type of festival-or the festival with a "business agenda" (as opposed to an "audience" festival, or a 
festival that has a "geopolitical agenda," for example). ${ }^{3}$ The quintessential "business" festival is Cannes. This festival is so excessively industry oriented-it excludes the audience almost entirely - that many have argued that it should be classified as an industry event rather than a film festival. Indeed, a group of international scholars have proposed that there should be a separate subfield of "Cannes studies." "Business agenda" festivals also include all those that, over the years, have built up markets and industry networking forums: festivals like Berlinale, Venice International Film Festival (IFF), Toronto IFF, Busan IFF, International Documentary Film Festival, and Amsterdam (IDFA), as well as events in Karlovy Vary, Thessaloniki, Rotterdam, and many more.

This essay focuses particularly on the festival activities that are specifically intended to foster production. However, one must say that, historically, festivals embraced the distribution function first. Indeed, holding parallel markets that facilitated the circulation of new films has been a feature of the Cannes event for many years. In the last decade, however, it is Berlinale and Busan that have garnered the most attention for developing distribution arms. By building its European Film Market in February (and thus early in the calendar year), as of 2001 Berlinale successfully garnered most parts of the film business that had lost access to a single central venue for sales after the collapse of Europe's oldest and best-established autumn film market in Milan (International Market for Cinema and Multimedia; 1960-2005). ${ }^{4}$ After emerging as a new kid on the block in 1996, within a decade or so, Busan successfully appropriated most of the Asian film business, rivaling much older and better-known festivals such as those in Hong Kong and Tokyo. One can claim that Busan not only took over existing business from these older festivals and their adjacent market ventures but also developed and expanded the intraAsian market for visual products to unprecedented proportions.

Recently, a growing number of festival organizations have been capitalizing on the fact that filmmakers, producers, and other professionals congregate for annual festival events and have sought to exploit the presence of these production-oriented stakeholders. Berlinale, for example, pioneered the Talent Campus in 2003. Busan followed in 2005 with its Asian Film Academy (AFA). Many other festivals provide forum space for interpersonal encounters and negotiations between companies and creatives, or hold special events (pitching sessions, development fund awards, sessions for additional financing rounds) that foster production-related activities as part of their festivals. Now so many pitching forums take place across festivals that there are individuals who work the circuit and specialize in hosting such forums; these experts know what films are on offer and who is able and willing to invest in up-and-coming productions. One such individual is Martin Blaney, a journalist at Screen International, who spends significantly more time at pitching engagements across the world than writing stories. Another forum host is the "new world of distribution" consultant Peter Broderick, who also delivers his services mainly through the festival circuit.

"The festival pitch" has become such an established practice that even though many filmmakers have come to recognize the reality of spiraling costs and lessened effectiveness (measured by the smaller stream of incoming investments realized by presenting at festival pitching sessions), the belief that it is essential to pitch still persists. According to a recent survey that scrutinized the cost of attending a pitching forum (based on the official IDFA Forum statistics and list of fees), observers must pay between $€ 200$ and $€ 300$ and participants between $€ 300$ and $€ 400$ per person to attend the forum. IDFA earns between $€ 80,000$ and $€ 90,000$ in revenue from pitching forum fees during each festival. ${ }^{5}$ And even though most interviewees expressed reservations about the effectiveness of attending pitching forums and seemed to consider them wasteful, 
they all acknowledged that online pitching was not a viable alternative, that continued festival attendance is important, and that a representative trailer for their projects should be shown in the context of film festival forums.

New Crowned Hope Festival in Vienna, Austria, was the first festival to engage in direct commissioning of film productions: in 2006, it commissioned films from Asian directors such as Apichatpong Weerasethakul (Thailand) and Garin Nugroho (Indonesia). Long before that, however, festivals distributed production funds to a line of projects that were in the production pipeline and that competed with each other for supplementary funds made available by the respective festivals' schemes. For example, Marco Muller's Montecinemaverita Foundation has operated at Locarno since the 1990s, and Scandinavian festivals have awarded various production funds to filmmakers from across the Third World.

More than a decade ago, the late cultural critic Paul Willemen claimed that although festivals may seem to open up pathways to global exposure and circulation, in fact, they only produce a "bottleneck effect" and ensure that noncommercial films remain outside formal circulation channels. Traditional circulation channels, meanwhile, remain reserved for blockbuster-type mainstream cinema. Festivals, Willemen claimed, do not bring cinema closer to the people. On the contrary, they encapsulate and isolate cinema, shielding it from wider audiences, and thus effectively shrink all chances of proper exposure. ${ }^{6}$ Other authors who study the festival galaxy, however, do not feel that festivals play such a restrictive function. ${ }^{7}$ In order to balance multiple opinions, one should say that, like most cultural phenomena, film festivals are multifaceted and riddled with inherent contradictions. Festivals enhance the exposure of films, but they also disrupt the traditional distribution process; they may appear networked, but there is also evidence to the contrary. Most importantly, the importance of the film festival as a node in the cinema production and distribution cycle is becoming increasingly recognized by all stakeholders involved in the festival operation, from board members to filmmakers, producers, and critics.

My own research questions gradually crystallized around these dichotomies. They are distilled here in order to reveal several issues explored by my work on festivals, including the importance of film festivals in the context of film culture at large, the reigning logic within the film festival galaxy, and the key features and stakeholders of the film festival. What, if anything, is wrong with the concept of "festival films"? What makes a good film festival good or a bad one bad?

A mere decade ago, only a handful of publications touched on matters related to film festivals. In recent years, the situation has changed dramatically, with abundant new writing and publications; some even speak of film festival studies as "a field," and a "burgeoning" one at that. 8

Today, we are witnessing the appearance of a host of studies highlighting important concrete details in the history of cinema and its localization (and globalization) via various festivals studies that delve deeper into specific aspects of this or that festival, and highlight previously discounted matters of interest. ${ }^{9}$ All of these efforts are important in bringing our attention to key phenomena that have been overlooked and denied existence for years; one needs to encourage the compensatory efforts that drive such current scholarship. There is consensus among scholars that media industries research needs to study how the film festival structures and narrates itself, what its components are, what constitutes the play of power between its participants, and how this is reenacted in the time and space of the festival and even beyond. 
Once such an understanding has been settled, it will lead us to further studies analyzing how the festival inscribes itself into the context of its locality and how it insinuates itself into the global galaxy of other festivals. To employ a technological metaphor in this technological age, such examination focuses on the festival's "hardware" (venues, hub), its "software" (films, programming, sidebars), and the "interface" of its components (the coverage, the party).

${ }^{1}$ Dina Iordanova has published over fifteen books dealing with matters of global film circulation, film festivals, digital disruption, European cinema (with focus on Eastern Europe and the Balkans), migration, global film, and media. She is Professor and Director of the Institute of Global Cinema and Creative Cultures at the University of St Andrews in Scotland. Her work is translated in numerous languages. Her most recent edited volume (with Stefanie Van de Peer) is exploring Film Festivals and the Middle East (2014).

2 Dina Iordanova, "The Film Festival Circuit," in Film Festival Yearbook 1: The Festival Circuit, ed. Dina Iordanova and Ragan Rhyne (St. Andrews: St Andrews Film Studies with College Gate Press, 2009), 23-39.

3 Kenneth Turan, Sundance to Sarajevo: Film Festivals and the World They Made (Berkeley: University of California Press, 2002); Mark Peranson, "First You Get the Power, Then You Get the Money: Two Models of Film Festivals," in Dekalog 3: On Film Festivals, ed. Richard Porton (London: Wallflower, 2009), 23-37.

4 Dom Serafini, "My 2 Cents: Who Killed MIFED?," Video Age: The Business Journal of Film, TV, Broadcasting, Broadband, Production, Distribution (2005).

5 “The Festival Pitch," DOX: European Documentary Magazine (2012/2013): 5-10.

6 Dina Iordanova, introduction to The Film Festival Reader, ed. Dina Iordanova (St. Andrews: St Andrews Film Studies, 2013), 1.

7 Thomas Elsaesser, "Film Festival Networks: The New Topographies of Cinema in Europe," in European Cinema: Face to Face with Hollywood (Amsterdam: Amsterdam University Press, 2005), 82-107; Jean-Michele Frodon, "The Cinema Planet" (lecture, Centre for Film Studies at the University of St Andrews, November 9, 2010).

8 Marijke De Valck and Skadi Loist, "Film Festival Studies: An Overview of a Burgeoning Field," in Film Festival Yearbook 1: The Festival Circuit, ed. Dina Iordanova and Ragan Rhyne (St. Andrews: College Gate Press, 2009), 179-215.

9 For a listing of published writing related to film festival, please see the FFRN Research Bibliography available at http://www.filmfestivalresearch.org/index.php/ffrnbibliography/. 


\section{Bibliography}

De Valck, Marijke, and Skadi Loist. “Film Festival Studies: An Overview of a Burgeoning Field." In Film Festival Yearbook 1: The Festival Circuit, edited by Dina Iordanova and Ragan Rhyne, 179-215. St. Andrews: College Gate Press, 2009.

Elsaesser, Thomas. “Film Festival Networks: The New Topographies of Cinema in Europe." In European Cinema: Face to Face with Hollywood, 82-107. Amsterdam: Amsterdam University Press, 2005.

Frodon, Jean-Michele. "The Cinema Planet." Lecture, Centre for Film Studies at the University of St Andrews, November 9, 2010.

Iordanova, Dina. “The Film Festival Circuit." In Film Festival Yearbook 1: The Festival Circuit, edited by Dina Iordanova and Ragan Rhyne, 23-39. St. Andrews: St Andrews Film Studies with College Gate Press, 2009.

Iordanova, Dina. Introduction to The Film Festival Reader, edited by Dina Iordanova, 1-19. St. Andrews: St Andrews Film Studies, 2013.

Peranson, Mark. "First You Get the Power, Then You Get the Money: Two Models of Film Festivals." In Dekalog 3: On Film Festivals, edited by Richard Porton, 23-37. London: Wallflower, 2009.

Serafini, Dom. “My 2 Cents: Who Killed MIFED?" Video Age: The Business Journal of Film, TV, Broadcasting, Broadband, Production, Distribution (2005).

“The Festival Pitch.” DOX: European Documentary Magazine (2012/2013): 5-10.

Turan, Kenneth. Sundance to Sarajevo: Film Festivals and the World They Made. Berkeley: University of California Press, 2002.

\section{(cc) $\mathrm{Br}-\mathrm{NC}-\mathrm{ND}$}

Copyright (C) 2015 (Dina Iordanova). Media Industries is an open-access, peer-reviewed, online academic journal. As such, we aim to participate in the open exchange of information. This work is licensed under a Creative Commons Attribution Noncommercial No Derivatives (by-nc-nd) License. Under this license, this work is available for sharing and noncommercial distribution provided the appropriate attribution is given. 